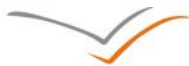

\title{
VERSITA
}

\section{Business Challenges and Design: Theory and Practice in the Furniture Industry in the Republic of Croatia}

\author{
Romina Radović, M.Sc. \\ Romicom, d.o.o., Zagreb, Croatia
}

\begin{abstract}
Background: A systematic and continuous product policy management is important for a company's competitiveness and the question is to what extent and in what way companies engaged in the furniture manufacturing sector actually apply them. Objectives: The objective of this paper is to explore to what extent the design profession is involved in the product policy and teams which define market properties of products in the furniture industry. Methods: In order to achieve the objectives of this paper, the Model for Exploring the Role of Design in Defining Market Properties and the Product Policy in the Furniture Industry has been devised. Two surveys have been conducted, measuring the level of involvement of the design profession in the product policy, as well as the involvement of designers in the work of teams which define market properties of products in the furniture industry. Results: The design profession is not systematically and continuously involved in the function of the product policy as the key component in programming a company's development and growth in the furniture industry. Conclusions: Companies engaged in furniture manufacturing should consider the possibility of involving design managers in coordination and management of product development, as well as in communication coordination on the manufacturer designer level.
\end{abstract}

Key words: market properties of products, product policy, new product, industrial design, product design, design, designer, furniture industry

JEL main category: Business Administration and Business Economics \& Marketing JEL classification: L21, L23, D02

Paper type: Research article

Received: 23, June, 2013

Revised: 8, October, 2013

Accepted: 12, November, 2013

Citation: Radovic, R. (2013). "Business Challenges and Design: Theory and Practice in the Furniture Industry in the Republic of Croatia", Business Systems Research, Vol. 4, No. 2, pp. 7993.

DOI: 10.2478/bsri-2013-0014

\section{Introduction}

Wood processing and furniture manufacturing have a significant role in national economy which is reflected in their economic as well as wider social contribution, and which largely contributes to harmonisation of the overall domestic development processes. Wood processing and furniture manufacturing hold $7 \%$ share in the export of products in Croatia for 2009 , of which $3 \%$ refer to furniture manufacturing and $4 \%$ to wood processing. Additionally, wood processing and furniture manufacturing hold one-third of the overall number of 
employees in the processing industry and $0.9 \%$ share in the gross social product for 2009 , as specified in the Operative Programme for Development of Wood Processing and Furniture Manufacturing 2011-2014 (Ministry of Regional Development, Forestry and Water Management, 2011).

It can be noticed every day that the existing "domestic" companies engaged in furniture manufacturing find it ever more difficult to cope with competition of large international organisations and associations. In production, marketing and particularly in advertising terms, those organisations are incomparably stronger and more capable of offering better financial and delivery-related terms in each tender, although they are not necessarily the most appropriate ones for the client. In this respect, a systematic and continuous product policy management as well as adequate definition of furniture market properties is important for company's competitiveness and the question is how to define them properly.

By carrying out a systematic market assessment, applying the methods for contemporary product management, defining the project task and market properties which are expected from the new product, as well as by defining the product policy, the risk for product's market success is reduced. If the company which has determined to develop a new product is familiar with the market in which it wishes to launch such product, if it sets the requirements pertaining to the product in the project task at the beginning of development process and if it implements adequate product management policies, the market success of the new product should be visible. Designers are educated to respond to each task set before them by applying certain methods. Developing a new product and investing in the entire process of product development is a risky process and there are numerous reasons for the failure of new products. It is frequently the case that new products, despite the effort and funds invested in them; do not become prominent in the market. The company management usually raise, to them a logical question concerning the return of investment in developing a new product. The design ROI (return of investment) calculation has been the subject matter of research and concern of professional design managers for years. The reason for this is something known as "design paradox", which is contrary to the afore mentioned advantages of applying design in the business process, and which consequently results in the reluctance to invest in a new product. Perhaps they should stop requesting the return of investment and focus on the return of expectations (ROE).

A good design requests thinking about everything a customer does when he buys, uses or throws away a product. The crucial element is to know who the target customer is (Kotler, 2004).This implies an interdisciplinary knowledge and interdisciplinary team of colleagues in developing a new product. In a systematic and organised industry, an industrial designer should be involved in product development from the very beginning of defining the project task or the so called "briefing", which means providing design instructions. The notion of "briefing" refers to design instruction. In formal sense, this design instruction does not have a formal layout and it is composed by a person/team, or anybody who has something to say about the nature of the new product. It is information for a designer regarding future activities.

Market properties of furniture as a product comprise numerous components: aesthetic, technical, functional, ergonomic component, price, labelling and product arrangement, advertising, quality component, product range or mixture and contemporariness (Previšić et al. 1999). The product policy implies systematic and continuous market research on which an organised, systematic and continuous process of product innovation is based (Previšic et al. 1999).

Keller (1975) points out that, in terms of design, each product and thus subsequently furniture as a product itself, are determined by interdependent design factors. Thereby, aesthetics, motivation, function, ergonomics, mechanism, structure, manufacturing, economics and presentation are intertwined and they become relevant in relation to certain design parameters they influence such as the use, sale and manufacturing (Keller, 1975). Unfortunately, in the mass perception, the term design is mostly related to luxury goods to such an extent that the endeavour to understand its true meaning is probably lost. Product's aesthetic component is highlighted, in line with modern perception of design mostly dealt with by the lifestyle rubric of daily newspapers. At the same time, the equally important properties such as functionality (efficiency, ergonomics, durability) and productivity 
(technological feasibility, economic production and distribution) tend to be forgotten. At the present time, ecological, ergonomic and especially ethical product component are becoming more prominent.

There is an awareness about the importance of design in defining furniture market properties, which is substantiated by the activities of numerous consulting companies, such as the international competition for the design of furniture, organized by USAID and Competitiveness Initiative in 2004, state institutions and similar organisations which encourage product design competitions and collaboration between designers and manufacturers. However, it is frequently the case that such competitions sadly end up without any long-term collaboration having been established between designer and manufacturer or without any significant commercial success of the new products.

In Croatia, design has been present in the wood industry for years. Having lost a large market share in the region and due to many other objective economic and political factors in the last twenty years, numerous companies were not able to find their way in international market, and from local leaders they turned into companies which carry out solely lohn business, or they vanished from the market as business entities. While developing their products, manufacturing companies do not involve designers and the product is not their intellectual property - it is manufactured exclusively at the lower price, for a familiar client. Under such circumstances, the profitability of those companies is low, despite the high safety level of the job. On the other hand, those companies which manufacture the furniture according to their own design do not involve a team of experts, or a designer, in defining all market properties of the product. Within various initiatives to improve sector competitiveness, numerous research projects have been conducted on the need to involve designers in development processes in the furniture industry in the Republic of Croatia. However, such research projects do not perform an in-depth research of the product development process (Ministry of Regional Development, Forestry and Water Management, 2010, and Croatian Design Centre, Ministry of Agriculture, Forestry and Water Management, 2005) itself and design process within the company, where its market properties and product policy are defined, which should also determine the market position of the final product.

Due to the fact that a higher level of involvement of designers in the expert team while defining products' market properties, as well as the implementation of design policy in the product policy would increase the competitiveness of Croatian companies engaged in furniture manufacturing, it was important to further investigate the way in which designers are involved in the teams which define the above mentioned components of products' market properties.

Pursuant to the above, the work hypotheses have been defined. The first hypothesis implies that, due to the lack of their market orientation, Croatian companies engaged in the furniture industry do not possess a defined product policy; hence design profession does not constitute a part of such policy. The second hypothesis implies that, due to the lack of their marketing orientation, Croatian companies engaged in the furniture industry consciously do not define market properties of products which are expected to ensure market competitiveness. Therefore, design profession is not involved in the teams which define such properties of the future product.

\section{Research Methodology}

With a purpose to obtain the data used for testing the hypotheses presented in this paper, a primary research has been conducted. Two surveys have been developed measuring the level of involvement of design profession in the function of product policy as the key component in programming the development and growth of companies in the furniture industry, as well as in the work of teams which define product's market properties in the furniture industry.

The surveying method consisted of filling out online surveys by the respondents. Prior to conducting the real research, the survey was pre-tested on a small representative sample, in written form. The pre-testing results showed that the survey was too extensive and that respondents were not likely to answer all the questions in the questionnaire, or the whole survey itself. Because of that, adjusted questions were chosen and their scope was reduced 
in order to obtain the expected results. The survey was conducted on a sample of companies whose primary activities are C31-Furniture manufacturing, according to NKD 2007 classification. According to the information obtained from the Croatian Chamber of Economy, in 2010 there were a total of 569 companies primarily engaged in those activities, which submitted the annual financial report for the period of previous year. According to the Accounting Act, they are classified into, 4 large companies, 24 medium-sized companies and 541 small companies (Accounting Act, 2007). A stratified sample with a planned size of 200 companies was used and the sample included all large and medium-sized companies, whereas the rest were small companies. The expected return amounted to 20-30\%. In the companies, the survey was conducted among the persons responsible for decision making and defining market properties and product policies. According to the available data, there are 569 registered and active companies, which at the same time represent the basic group. The survey was conducted on the sample of 200 companies, which is the size of the planned sample, with a maximum expected margin of error of $\pm 7.1 \%$.

The survey was also conducted on the sample of professional product and industrial designers (hereinafter: designer) who are members of at least one professional association, including Croatian Designers Society (HDD), Croatian Association of Artists of Applied Artsproduct design section (ULUPUH) and/ or Industrial Design Society at Design Centre of the Croatian Chamber of Economy (ZzID). In this paper, the term designer denotes a person who has completed the adequate professional training, possesses adequate expertise and who is engaged in industrial, product or interior design in his/her work. This paper does not observe the work of designers engaged primarily in graphic design and visual communication design, or fashion designers.

According to the information obtained from the associations mentioned above, in 2011 they had a total of 161 members. According to the information obtained from professional associations, there are 161 registered and active professional designers, who at the same time represent the basic group. The survey was conducted on the sample of 110 professional designers, which is the size of the planned sample, with a maximum expected margin of error of $\pm 10 \%$.

The first hypothesis was tested by using the questions measuring the level of involvement of designers in the function of product policy, as the key component in programming the growth and development of companies engaged in the furniture industry where the level of involvement was measured by statements of involvement and Likert scale. The share of products for whose definition of product policy the designers were systematically and continuously involved was also measured. Identical questions were asked to both responsible persons in companies and professional designers.

The second hypothesis was tested by using the questions measuring the level of involvement of designers in the work of teams which define product properties in the furniture industry, where the level of involvement was measured by statements of involvement and Likert scale. The share of products for whose definition of product policy the designers were systematically and continuously involved was also measured. Identical questions were asked to both responsible persons in companies and professional designers.

\section{Research Results}

Figure 1 shows the differences between designers' engagement in the process of development, prototyping and product redesign and the business practice of the sample company in \%. A difference in responses obtained from designers and sample companies may be observed. For example, $17 \%$ of sample companies used designers' services for developing products/product line, whereas $20 \%$ designers participated in the development of products/product line. Such a difference exists due to the fact that companies engaged several designers for product development, whereas certain designer was able to cooperate with several companies. Based on this difference, it may be concluded that only a small number of companies use designers' services during product development, whereby they engage several designers instead of relying on the services of one designer only. 
Figure 1

Differences between designer's engagement in the process of development, prototyping and product redesign and the business practice of the sample company in \%

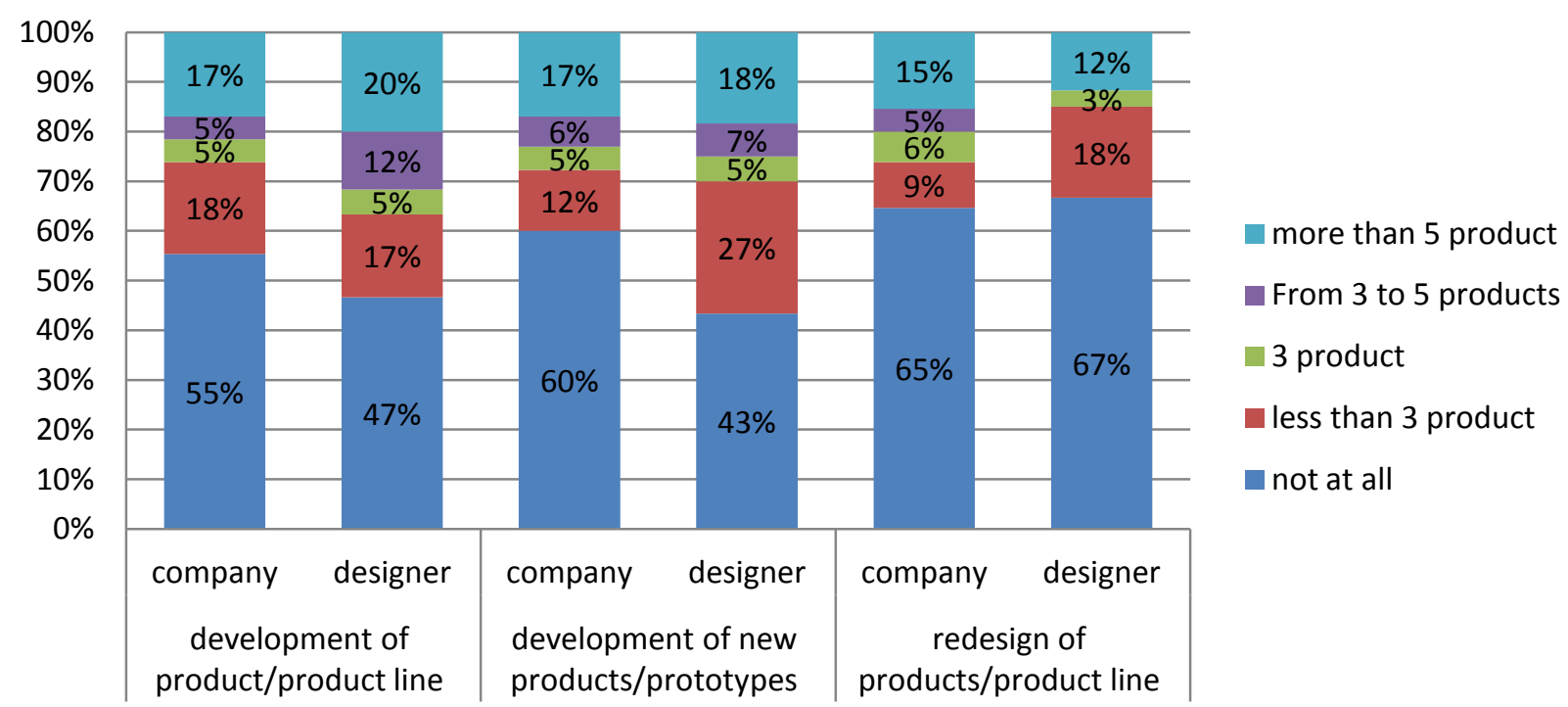

Source: Author's work

In order to determine whether the obtained results are statistically significant, a chi-square test was conducted which showed that for neither of the above mentioned activities a statistically significant difference exists between a company and a designer: development of product/product line $\left(X^{2}=2,630 ; p\right.$-value $\left.=0,622\right)$; development of new products/prototypes $\left(X^{2}=5,075 ; p\right.$-value $\left.=0,282\right)$; redesign of products/product line $\left(X^{2}=5,524 ; p\right.$-value $\left.=0,622\right)$.

Table 1

The difference between designers' engagement in defining product components and business practise of the company represented in the sample in \%

\begin{tabular}{|c|c|c|c|c|c|c|}
\hline & & Never & Rarely & Sometimes & Frequently & Always \\
\hline \multirow[t]{2}{*}{ Aesthetic component } & Designer & $23 \%$ & $3 \%$ & $5 \%$ & $18 \%$ & $50 \%$ \\
\hline & Company & $45 \%$ & $12 \%$ & $11 \%$ & $14 \%$ & $18 \%$ \\
\hline \multirow{2}{*}{$\begin{array}{l}\text { Technical and } \\
\text { technological } \\
\text { component }\end{array}$} & Designer & $23 \%$ & $8 \%$ & $13 \%$ & $27 \%$ & $28 \%$ \\
\hline & Company & $54 \%$ & $18 \%$ & $12 \%$ & $9 \%$ & $6 \%$ \\
\hline \multirow{2}{*}{$\begin{array}{l}\text { Functional and } \\
\text { ergonomic } \\
\text { component }\end{array}$} & Designer & $25 \%$ & $7 \%$ & $10 \%$ & $22 \%$ & $37 \%$ \\
\hline & Company & $51 \%$ & $14 \%$ & $14 \%$ & $12 \%$ & $9 \%$ \\
\hline \multirow{2}{*}{$\begin{array}{l}\text { Product price } \\
\text { component }\end{array}$} & Designer & $33 \%$ & $13 \%$ & $23 \%$ & $17 \%$ & $13 \%$ \\
\hline & Company & $68 \%$ & $17 \%$ & $6 \%$ & $6 \%$ & $3 \%$ \\
\hline \multirow{2}{*}{$\begin{array}{l}\text { Product labelling and } \\
\text { design }\end{array}$} & Designer & $35 \%$ & $15 \%$ & $13 \%$ & $25 \%$ & $12 \%$ \\
\hline & Company & $62 \%$ & $12 \%$ & $12 \%$ & $8 \%$ & $6 \%$ \\
\hline \multirow[t]{2}{*}{ Product packaging } & Designer & $40 \%$ & $18 \%$ & $22 \%$ & $12 \%$ & $8 \%$ \\
\hline & Company & $71 \%$ & $12 \%$ & $8 \%$ & $8 \%$ & $2 \%$ \\
\hline \multirow{2}{*}{$\begin{array}{l}\text { Defining services for } \\
\text { customers, }\end{array}$} & Designer & $42 \%$ & $13 \%$ & $18 \%$ & $13 \%$ & $13 \%$ \\
\hline & Company & $66 \%$ & $17 \%$ & $6 \%$ & $6 \%$ & $5 \%$ \\
\hline \multirow{2}{*}{$\begin{array}{l}\text { Advertising product } \\
\text { component }\end{array}$} & Designer & $30 \%$ & $18 \%$ & $20 \%$ & $22 \%$ & $10 \%$ \\
\hline & Company & $52 \%$ & $17 \%$ & $14 \%$ & $8 \%$ & $9 \%$ \\
\hline \multirow{4}{*}{$\begin{array}{l}\text { Product quality } \\
\text { component } \\
\text { Range or product mix }\end{array}$} & Designer & $30 \%$ & $10 \%$ & $18 \%$ & $23 \%$ & $18 \%$ \\
\hline & Company & $55 \%$ & $17 \%$ & $11 \%$ & $8 \%$ & $9 \%$ \\
\hline & Designer & $38 \%$ & $13 \%$ & $15 \%$ & $18 \%$ & $15 \%$ \\
\hline & Company & $65 \%$ & $9 \%$ & $11 \%$ & $9 \%$ & $6 \%$ \\
\hline \multirow{2}{*}{$\begin{array}{l}\text { Contemporary nature } \\
\text { of products }\end{array}$} & Designer & $23 \%$ & $10 \%$ & $10 \%$ & $30 \%$ & $27 \%$ \\
\hline & Company & $52 \%$ & $9 \%$ & $17 \%$ & $12 \%$ & $9 \%$ \\
\hline
\end{tabular}

Source: Author's work 
Table 1 shows the difference between designers' engagement in defining product components and business practice of the company represented in the sample in \%. It may be noticed that designers report they were more frequently engaged in determining certain product components in relation to the business practice of all sample companies together. It may be again concluded that designers are engaged in a small number of active companies, whereas a large number of companies do not engage designers or engage them only for determining several basic components.

In order to determine whether the established differences are statistically significant, a chisquare test was conducted (Table 2) which proved the statistically significant difference between designers' engagement and company's engagement for the following product components: e.g. aesthetic component, technical and technological component, functional and ergonomic component, price component, product labelling and design, product packaging, defining services for customers, and product quality component.

Table 2

Results of chi-square test, the difference of designers' engagement in defining product components in relation to business practise of the company represented in the sample in \%

\begin{tabular}{lrrr}
\hline & $X^{2}$ & $d f$ & $p$ - value \\
\hline Aesthetic component & 18,176 & 4 & $0,001^{* *}$ \\
Technical and technological component & 24,314 & 4 & $0,000^{* *}$ \\
Functional and ergonomic component & 19,438 & 4 & $0,001^{* *}$ \\
Product price component & 21,034 & 4 & $0,000^{* *}$ \\
Product labelling and design & 11,614 & 4 & $0,020^{*}$ \\
Product packaging & 13,766 & 4 & $0,008^{* *}$ \\
Defining services for customers & 11,930 & 4 & $0,018^{*}$ \\
Advertising product component & 8,721 & 4 & 0,068 \\
Product quality component & 13,915 & 4 & $0,008^{* *}$ \\
Range or product mix & 9,298 & 4 & 0,054 \\
Contemporary nature of products & 18,024 & 4 & $0,001^{* *}$ \\
\hline
\end{tabular}

* statistically significant with $5 \%$ probability, ${ }^{* *}$ statistically significant with $1 \%$ probability

Source: Author's work

Table 3

Difference between designers' engagement in defining product components and designers' attitude about the need of their involvement in \%

\begin{tabular}{|c|c|c|c|c|c|c|}
\hline & & Never & Rarely & Sometimes & Frequently & Always \\
\hline \multirow[t]{2}{*}{ Aesthetic component } & Really & $23 \%$ & $3 \%$ & $5 \%$ & $18 \%$ & $50 \%$ \\
\hline & Expected & $2 \%$ & $2 \%$ & $2 \%$ & $2 \%$ & $93 \%$ \\
\hline \multirow{2}{*}{$\begin{array}{l}\text { Technical and technological } \\
\text { component }\end{array}$} & Really & $23 \%$ & $8 \%$ & $13 \%$ & $27 \%$ & $28 \%$ \\
\hline & Expected & $3 \%$ & $3 \%$ & $7 \%$ & $42 \%$ & $45 \%$ \\
\hline \multirow{2}{*}{$\begin{array}{l}\text { Functional and ergonomic } \\
\text { component }\end{array}$} & Really & $25 \%$ & $7 \%$ & $10 \%$ & $22 \%$ & $37 \%$ \\
\hline & Expected & $2 \%$ & $2 \%$ & $3 \%$ & $12 \%$ & $82 \%$ \\
\hline \multirow{2}{*}{ Product price component } & Really & $33 \%$ & $13 \%$ & $23 \%$ & $17 \%$ & $13 \%$ \\
\hline & Expected & $5 \%$ & $3 \%$ & $23 \%$ & $52 \%$ & $17 \%$ \\
\hline \multirow[t]{2}{*}{ Product labelling and design } & Really & $35 \%$ & $15 \%$ & $13 \%$ & $25 \%$ & $12 \%$ \\
\hline & Expected & $3 \%$ & $2 \%$ & $12 \%$ & $30 \%$ & $53 \%$ \\
\hline \multirow[t]{2}{*}{ Product packaging } & Really & $40 \%$ & $18 \%$ & $22 \%$ & $12 \%$ & $8 \%$ \\
\hline & Expected & $3 \%$ & $5 \%$ & $8 \%$ & $32 \%$ & $52 \%$ \\
\hline \multirow[t]{2}{*}{ Defining services for customers } & Really & $42 \%$ & $13 \%$ & $18 \%$ & $13 \%$ & $13 \%$ \\
\hline & Expected & $5 \%$ & $8 \%$ & $15 \%$ & $52 \%$ & $20 \%$ \\
\hline \multirow[t]{2}{*}{ Advertising product component } & Really & $30 \%$ & $18 \%$ & $20 \%$ & $22 \%$ & $10 \%$ \\
\hline & Expected & $3 \%$ & $5 \%$ & $18 \%$ & $43 \%$ & $30 \%$ \\
\hline \multirow[t]{2}{*}{ Product quality component } & Really & $30 \%$ & $10 \%$ & $18 \%$ & $23 \%$ & $18 \%$ \\
\hline & Expected & $3 \%$ & $3 \%$ & $5 \%$ & $37 \%$ & $52 \%$ \\
\hline \multirow[t]{2}{*}{ Range or product mix } & Really & $38 \%$ & $13 \%$ & $15 \%$ & $18 \%$ & $15 \%$ \\
\hline & Expected & $3 \%$ & $3 \%$ & $13 \%$ & $32 \%$ & $48 \%$ \\
\hline \multirow{2}{*}{$\begin{array}{l}\text { Contemporary nature of } \\
\text { products }\end{array}$} & Really & $23 \%$ & $10 \%$ & $10 \%$ & $30 \%$ & $27 \%$ \\
\hline & Expected & $2 \%$ & $2 \%$ & $3 \%$ & $10 \%$ & $83 \%$ \\
\hline
\end{tabular}

Source: Author's work 
Table 3 shows the difference between designers' engagement in defining product components and their attitude and expectations about what it should look like in practice in $\%$. It may be noticed that designers often say that they should be more frequently engaged in all categories, yet differences vary according to categories. In order to determine whether the established differences are statistically significant, a chi-square test was conducted (Table 4) which showed a statistically significant difference between designers' engagement and company's engagement for the following product components: e.g. aesthetic product component, technical and technological product component, functional and ergonomic product component, price product component, product labelling and design.

\section{Table 4}

The results of chi-square test on the difference between designers' engagement in defining product components and designers' attitude about the need of their involvement in \%

\begin{tabular}{lccc}
\hline & $X^{2}$ & df & p-value \\
\hline Aesthetic component & 28,794 & 4 & $0,000^{* *}$ \\
Technical and technological component & 15,867 & 4 & $0,003^{* *}$ \\
Functional and ergonomic component & 28,118 & 4 & $0,000^{* *}$ \\
Product price component & 27,144 & 4 & $0,000^{* *}$ \\
\hline Product labelling and design & 38,461 & 4 & $0,000^{* *}$ \\
Product packaging & 51,059 & 4 & $0,000^{* *}$ \\
Defining services for customers, & 32,542 & 4 & $0,000^{* *}$ \\
Advertising product component & 27,748 & 4 & $0,000^{* *}$ \\
Product quality component & 30,673 & 4 & $0,000^{* *}$ \\
Range or product mix & 33,958 & 4 & $0,000^{* *}$ \\
Contemporary nature of products & 40,353 & 4 & $0,000^{* *}$ \\
\hline
\end{tabular}

** statistically significant with $1 \%$ probability

Source: Author's work

Table 5

Difference between designers' engagement in defining product components and designer's attitude about the need of their involvement in \%

\begin{tabular}{|c|c|c|c|c|c|c|}
\hline & & Never & Rarely & Sometimes & Frequently & Always \\
\hline \multirow[t]{2}{*}{ Expected product price } & Really & $32 \%$ & $13 \%$ & $15 \%$ & $22 \%$ & $18 \%$ \\
\hline & Expected & & $7 \%$ & $10 \%$ & $25 \%$ & $58 \%$ \\
\hline \multirow[t]{2}{*}{ Product designation } & Really & $17 \%$ & $7 \%$ & $10 \%$ & $28 \%$ & $38 \%$ \\
\hline & Expected & & & $3 \%$ & $10 \%$ & $87 \%$ \\
\hline \multirow{2}{*}{$\begin{array}{l}\text { Sales network through which } \\
\text { the product should be } \\
\text { marketed }\end{array}$} & Really & $37 \%$ & $27 \%$ & $17 \%$ & $7 \%$ & $13 \%$ \\
\hline & Expected & & $2 \%$ & $27 \%$ & $32 \%$ & $40 \%$ \\
\hline \multirow{2}{*}{$\begin{array}{l}\text { Technical and technological } \\
\text { requirements }\end{array}$} & Really & $30 \%$ & $12 \%$ & $10 \%$ & $32 \%$ & $17 \%$ \\
\hline & Expected & & & $7 \%$ & $22 \%$ & $72 \%$ \\
\hline \multirow{2}{*}{$\begin{array}{l}\text { Markets where product shall } \\
\text { be sold }\end{array}$} & Really & $30 \%$ & $18 \%$ & $20 \%$ & $18 \%$ & $13 \%$ \\
\hline & Expected & & & $13 \%$ & $32 \%$ & $55 \%$ \\
\hline \multirow[t]{2}{*}{ Norms to be fulfilled } & Really & $32 \%$ & $17 \%$ & $20 \%$ & $7 \%$ & $25 \%$ \\
\hline & Expected & & & $7 \%$ & $15 \%$ & $78 \%$ \\
\hline \multirow[t]{2}{*}{ Function to be fulfilled in use } & Really & $20 \%$ & $7 \%$ & $17 \%$ & $18 \%$ & $38 \%$ \\
\hline & Expected & & & $3 \%$ & $3 \%$ & $93 \%$ \\
\hline \multirow{2}{*}{$\begin{array}{l}\text { Ergonomic data vital for the } \\
\text { requested product }\end{array}$} & Really & $32 \%$ & $13 \%$ & $22 \%$ & $10 \%$ & $23 \%$ \\
\hline & Expected & & & $8 \%$ & $13 \%$ & $78 \%$ \\
\hline \multirow{2}{*}{$\begin{array}{l}\text { Information on the expected } \\
\text { sales }\end{array}$} & Really & $47 \%$ & $17 \%$ & $17 \%$ & $7 \%$ & $13 \%$ \\
\hline & Expected & & $2 \%$ & $25 \%$ & $43 \%$ & $30 \%$ \\
\hline \multirow{6}{*}{$\begin{array}{l}\text { Information regarding the } \\
\text { envisaged sales method } \\
\text { Information regarding the } \\
\text { envisaged distribution method } \\
\text { Design index }\end{array}$} & Really & $38 \%$ & $22 \%$ & $22 \%$ & $3 \%$ & $15 \%$ \\
\hline & Expected & & $3 \%$ & $28 \%$ & $32 \%$ & $37 \%$ \\
\hline & Really & $45 \%$ & $23 \%$ & $17 \%$ & $3 \%$ & $12 \%$ \\
\hline & Expected & & $5 \%$ & $32 \%$ & $33 \%$ & $30 \%$ \\
\hline & Really & $45 \%$ & $17 \%$ & $15 \%$ & $7 \%$ & $17 \%$ \\
\hline & Expected & & $2 \%$ & $17 \%$ & $17 \%$ & $65 \%$ \\
\hline
\end{tabular}

Source: Author's work 
Table 5 shows the difference between designers' engagement in product development in relation to their attitude and expectations about what it should look like in practice in \%. It may be noticed that designers often say they should be more frequently engaged in all categories, but differences vary according to categories.

The most significant differences were established in the following categories: product designation; norms to be fulfilled and product function. In order to determine whether the established differences are statistically significant, a chi-square test was conducted (Table 6) which proved the statistically significant difference between designers' engagement and company's engagement for the following aspects of product development: expected product price, product designation, sales network through which the product should be marketed, technical and technological requirements, markets where product shall be sold, norms to be fulfilled, function to be fulfilled in use, ergonomic data vital for the requested product, information regarding the envisaged sales method, information regarding the envisaged distribution method and design index.

Table 6

Results of chi-square test on the difference between designers' engagement in defining product components and designers' attitude about the need of their involvement in \%

\begin{tabular}{lccc}
\hline & $X^{2}$ & $d f$ & $p$-value \\
\hline Expected product price & 33,598 & 4 & $0,000^{* *}$ \\
Product designation & 32,474 & 4 & $0,000^{* *}$ \\
Sales network through which the product should be marketed & 54,403 & 4 & $0,000^{* *}$ \\
\hline Technical and technological requirements & 47,072 & 4 & $0,000^{* *}$ \\
Markets where product shall be sold & 48,828 & 4 & $0,000^{* *}$ \\
Norms to be fulfilled & 51,439 & 4 & $0,000^{* *}$ \\
Function to be fulfilled in use & 41,349 & 4 & $0,000^{* *}$ \\
Ergonomic data vital for the requested product & 48,694 & 4 & $0,000^{* *}$ \\
Information on the expected sales & 56,343 & 4 & $0,000^{* *}$ \\
Information regarding the envisaged sales method & 50,814 & 4 & $0,000^{* *}$ \\
Information regarding the envisaged distribution method & 56,478 & 4 & $0,000^{* *}$ \\
Design index & 54,151 & 4 & $0,000^{* *}$ \\
\hline
\end{tabular}

** statistically significant with $1 \%$ probability

Source: Author's work

With a purpose to test the hypotheses presented in this paper, an overview of statistical significances of the differences between designers' engagement and company's business practice has been made, as well as between designers' engagement and their expectations (Table 7).

The first hypothesis implies that design profession has not been systematically and continuously involved in the product policy as the key component in programming company's growth and development in the furniture industry, hence the items referring to product policy have been highlighted. Due to the fact that the conducted chi-square test showed that for most items referring to product policy there is a statistically significant difference between designer's engagement and company practice, it may be concluded that there are enough evidence to accept the first hypothesis presented in this paper. This conclusion was additionally confirmed by the existence of statistically significant differences between designers' engagement and their expectations regarding the function of product policy.

The second hypothesis implies that design profession has not been systematically and continuously involved in the teams which define market properties of products in the furniture industry, hence the items referring to product market properties have been highlighted. Due to the fact that the conducted chi-square test showed that for most items referring to product policy there is a statistically significant difference between designer's engagement and company practice, it may be concluded that there are enough evidence to accept the second hypothesis presented in this paper. This conclusion was additionally confirmed by the existence of statistically significant differences between designers' engagement and their expectations for items referring to market properties of products. 
Table 7

The overview of statistical significances of differences between designers' engagement and company's business practices, as well as between designers' engagement and their expectations

Differences between
designers' engagement and
company's business
practices

Differences between

designers' engagement and their expectations

\begin{tabular}{|c|c|c|}
\hline \multicolumn{3}{|c|}{ MARKET PROPERTIES OF PRODUCTS } \\
\hline Aesthetic component & $0,001^{* *}$ & $0,000^{* *}$ \\
\hline $\begin{array}{l}\text { Technical and technological } \\
\text { component }\end{array}$ & $0,000^{* *}$ & $0,003^{* *}$ \\
\hline Functional and ergonomic component & $0,001^{* *}$ & $0,000^{* *}$ \\
\hline Product price component & $0,000^{* *}$ & $0,000^{* *}$ \\
\hline Product labelling and design & $0,020^{*}$ & $0,000^{* *}$ \\
\hline Product packaging & $0,008 * *$ & $0,000^{* *}$ \\
\hline Defining services for customers & $0,018^{*}$ & $0,000^{* *}$ \\
\hline Advertising product component & 0,068 & $0,000^{* *}$ \\
\hline Product quality component & $0,008 * *$ & $0,000^{* *}$ \\
\hline Range or product mix & 0,054 & $0,000^{* *}$ \\
\hline Contemporary nature of products & $0,001^{* *}$ & $0,000^{* *}$ \\
\hline Expected product price & $0,002 * *$ & $0,000^{* *}$ \\
\hline Product designation & $0,000 * *$ & $0,000^{* *}$ \\
\hline $\begin{array}{l}\text { Sales network through which the } \\
\text { product should be marketed }\end{array}$ & $0,026^{*}$ & $0,000^{* *}$ \\
\hline $\begin{array}{l}\text { Technical and technological } \\
\text { requirements }\end{array}$ & $0,002^{* *}$ & $0,000^{* *}$ \\
\hline Markets where product shall be sold & $0,026^{*}$ & $0,000^{* *}$ \\
\hline Norms to be fulfilled & $0,003^{* *}$ & $0,000^{* *}$ \\
\hline Function to be fulfilled in use & $0,001^{* *}$ & $0,000^{* *}$ \\
\hline $\begin{array}{l}\text { Ergonomic data vital for the requested } \\
\text { product }\end{array}$ & $0,015^{*}$ & $0,000^{* *}$ \\
\hline \multicolumn{3}{|c|}{ FUNCTION OF PRODUCT POLICY } \\
\hline Information on the expected sales & $0,017^{*}$ & $0,000^{* *}$ \\
\hline $\begin{array}{l}\text { Information regarding the envisaged } \\
\text { sales method }\end{array}$ & $0,003^{* *}$ & $0,000^{* *}$ \\
\hline $\begin{array}{l}\text { Information regarding the envisaged } \\
\text { distribution method }\end{array}$ & $0,033^{*}$ & $0,000^{* *}$ \\
\hline Design index & $0,024^{*}$ & $0,000^{* *}$ \\
\hline
\end{tabular}

* statistically significant with $5 \%$ probability, ${ }^{* *}$ statistically significant with $1 \%$ probability Source: Author's work

\section{Discussion}

Increasing the Competitiveness of the Furniture Industry through Collaboration with Designers

This paper analysed the collaboration between designers and companies in relation to product development, defining tasks and providing design-related instructions. In a company, design is integrated in the marketing mix through all of its elements: product, price, distribution, advertising and strategic design management. In a broader sense, except for product management it also implies the managing all other areas through which design is integrated in the company: visual identity, manufacturers and product brand, manufacturer's environment. Design management implies company's market orientation and coordination of objectives. 
As it has already been presented in the previous part of this paper, the companies engaged in furniture manufacturing in the Republic of Croatia mostly do not involve industrial and product designers in their business policy, or product policy, neither do they involve designers in the teams which define market properties expected from a new product.

\section{The role of design in companies that are engaged in the production of furniture}

Design may be classified according to the method of integration in the company (Borja de Mozota, 2003). In this way, the design category, within a company, may refer to environment design (design of a work place, factories, store, showrooms etc.), product design, manufacturing design or manufacturing process design (tools and machines, commercial products), packaging design (commercial products, promotional materials) and graphic design (invitations, visual identity, logo, websites).

Moreover, design classification may also refer to the dimension of the shaped product, or 2D, 3D or 4D design (Borja de Mozota, 2003). 4D design refers to design process which is led by new technologies.

In practice, in the companies engaged in the furniture manufacturing sector design is mostly understood as a superficial tool aimed at decorating products or a tool for choosing somebody else's product which exists in the market and which needs to be imitated. The sector, as a whole, sees its comparative advantage mostly in the natural resource wealth. According to the research conducted in 2005 (Croatian Design Centre, Ministry of Agriculture, Forestry and Water Management, 2005) in the furniture industry in the Republic of Croatia there were only $35 \%$ companies which reported to possess a R\&D department for products, $50 \%$ manufacturers were not familiar with design process, and $35 \%$ of them were not interested in involving design in their business operations. According to the information presented in that research, mostly large companies and medium-sized companies to a lesser extent, used designers' services. The manufacturers mostly used the services of interior designers, showroom designers, website designers and graphic designers.

As it has been shown by the results of this research, while defining market properties of a new product the companies and designers have very little information regarding the price, distribution, packaging method, expected sale and markets in which the new product shall be launched. Considering the fact that such results mostly constitute the result of some previous research and familiar practice, it may be concluded that companies are not market oriented and they do not possess either a clear development strategy or a defined product policy. Without such basic information, however, the companies cannot be competitive in the market. The organised design management is carried out on three levels (Keller, G, 1975): world level, national level and company level. Without a fundamental understanding of the importance of design management within a company itself and by responsible persons in charge of decision making for the whole sector, it will not be possible to increase competitiveness regardless of the initiatives and strategies which are being implemented within the state institutions and, and the funds envisaged for such actions, until the moment their propositions and conclusions are implemented in practice. The prerequisite for their implementation is the existence of adequate knowledge to implement and coordinate the objectives on all levels.

In previous research projects (USAID and Competitiveness Initiative, 2003; Ministry of Regional Development, Forestry and Water Management, 2010; Croatian Design Centre, Ministry of Agriculture, Forestry and Water Management, 2005) which have been conducted on national level as part of various initiatives, the process of developing a new product itself and the role of design, as well as company organisation in furniture industry did not constitute research subjects so far. This, of course, is not the task of design management on the national level, but due to the fact that goals and the expected results of such initiatives required by tenders were actual products from which market success was expected, an actual result was consequently expected, as well (USAID Competitiveness Initiative, 2003). This requires a research and collaboration between a designer and the company in managing the process of new product development. In order to achieve the set objectives, the manufacturer, as a 
"basic unit" of furniture manufacturing sector, must not be neglected and the above mentioned objectives of a wider project must by synchronised with company goals.

The companies engaged in furniture manufacturing are mostly not market oriented. For this reason, the design process and product policy which involves design and innovation both in those environments and in the world are on the zero level of design application. In other words, design is not present in the business process but it serves as a decoration, as it is pointed out by Brooke Dobni (Brooke Dobni, 2010). Therefore it is not surprising that persons responsible for decision making in the companies engaged in furniture manufacturing are not aware of the importance of design and its strategic goals. A company's business decision, which need not necessarily be wrong, may be not to use the services of professional designers or to invest in development, but to carry out lohn business for familiar customers, for which they do not have to collaborate with a designer. However, if a business decision is to develop your own product from which market success is expected and which shall constitute an integral part of company's image, it is necessary to establish collaboration with experts from various fields of business and to ensure adequate process management. In a company, design management may be carried out on three following levels: (1) operative level or first step in design integration, (2) functional level or creating design function in a company and (3) strategic level or design capacity to unite and transform the company's vision (Borja de Mozota, 2003).

\section{Improve understanding and communication between the representatives of the companies and designers}

The results of this research which investigated the collaboration of professional designers experienced in collaboration with companies engaged in the furniture manufacturing sector and of companies which collaborated with designers, proved that design does not constitute an integral part of product development and therefore does not significantly influence the increase of product's added value. On the contrary, it is mostly applied in defining product's aesthetic component which has been confirmed by responses obtained from both companies and designers, as well as by previously conducted research projects (Guo, 2010).

The decision to develop a new product or redesign the existing one, as well as to withdraw it from manufacturing and sale, should be reached on the basis of continuous market research, as it is pointed out by Gorm et al. (2010). The lack of designers' involvement in the function of product policy in companies engaged in furniture manufacturing in the Republic of Croatia results from not being familiar with design and design methodology management, but also due to the fact that companies are not market oriented and do not possess a clear vision regarding their business operations. The companies in the furniture industry often list marketing department as a part of their organisational structure, yet they are not market oriented themselves and the marketing sector is usually reduced to sales function. The companies engaged in furniture manufacturing should critically observe their organisational structure, both formal and informal, and harmonise it with desired objectives and demands of contemporary and successful global business practice. Should they consider it necessary, they should also include design profession in their business operations as efficiently as possible.

Within this research, it has been observed that neither designers nor companies develop new products sufficiently, not even in the prototype phase. Companies redesign their products insufficiently and inadequately, whereas designers are mostly not involved in that process. Consequently, the companies do not use all possibilities to prolong the lifespan of their product in a quality and professional way. As it has been previously mentioned in this paper, the companies are mostly not market oriented and they do not possess a corresponding product policy. The research has shown that designers mostly do not collaborate with companies engaged in the furniture manufacturing sector, and they least collaborate in the activities related to product redesign or product line. Apart from developing new and innovative products, in order to become competitive in the market the companies should also redesign and modify their existing products and product lines. In this respect, the involvement of designers in such activities should be extremely important and therefore applied in practice. The research results showed that designers consider their 
engagement in that process as very important, yet it is unfortunately insufficiently implemented in practice.

The companies engage designers for defining product packages very rarely, from which it may be concluded that they do not consider such component as being really important. In furniture industry, packaging may constitute an important element through which a product could be presented, thus enabling the company to build its competitive advantage. This component might prove to be extremely important in furniture industry in case the company decided to implement new distribution channels (e.g. online sale).

According to respondents' answers, in most cases the companies do not provide designers with the information regarding the expected product price, or rarely provide such information, as well as other information regarding the expected sale, distribution method, markets in which the product shall be sold or any similar information which should result from the previously conducted research and familiar business practice. In their answers, designers said they mostly do expect such information. Therefore, the fact that active research and market assessment should be incorporated in the business process in order to enable the products in whose development lots of effort was invested to become prominent in the market, should represent an important information for companies. By carrying out adequate product policy and defining the market properties expected from the new product as well as by involving design profession in the business process and decision making, the furniture manufacturers may gain advantage over their competition.

Furthermore, furniture manufacturers in the Republic of Croatia do not possess a clear vision of product policy management and consequently they do not fully define the requirements pertaining to the new products. At the beginning of the process of defining a project task and design instructions, it is necessary to involve design profession alongside professionals from other fields, and present the information regarding market research and assessment. As it has been shown by results of this research, in practice the manufacturers do not define all properties expected from the future product, and consequently they are not submitted to designers. Certain information such as, for example, design index should preferably be gathered by both the manufacturer and designer and discussed accordingly. Certain properties defined by a project task may be modified and adjusted in the course of product development, but in this process it is important to define the expected product properties which would enable it to implement a meaningful product policy.

The results obtained by this research point out to insufficient or even bad communication and understanding between a designer and the company, which is a problem also recognised in other fields, as research results of the author named (Chittuiri, R.,2009) showed.

\section{Professional management and specialist knowledge to improve} competitiveness in furniture industry

Companies have several collaboration options at their disposal: a designer may be permanently employed in the company, or services of external design offices or freelance designers may be used. Foreign business practice showed that "in-house designers", or designers employed in the company, mostly perform the tasks of coordination and communication between the designer and the client, whereas in the companies engaged in furniture manufacturing sector they are more involved in product development. It is necessary to provide an adequate project management. The companies, just like designers, may also appoint, apart from other managing function, a design manager or a person who shall, among other things, be responsible for managing and coordinating the design processes and initiate communication between a manufacturer and designer in order to bridge the lack of confidence, misunderstandings and define a project task.

Contrary to the business practice of companies engaged in furniture manufacturing, once the product is defined, if it is innovative and new, it is necessary to protect its design. In this phase the company may, unless it possesses its own expertise, experience and human resources, use the services of IP - Intellectual Property Manager or an expert who possesses certain expertise and skills and who shall help the company to adequately protect its intellectual property rights in both domestic and international market, and simultaneously avoid to violate somebody else's rights. As it has been pointed out by Jolly (2011) in the 
introduction of "The Handbook of European Brand Rights Management", once the intellectual property rights are registered, they may be commercialised in numerous ways: it is possible to appoint a distributor, sell licence, grant franchise or develop the brand trough Merchandising.

According to the answers obtained from responsible persons, companies demonstrate an insufficient knowledge of both product and design management process. For this reason, designers and companies are unable to establish quality collaboration. The integration of design process in business operation may be obstructed by company management due to their behaviour and strong struggle, as it has been pointed out by Kotler and Rth. (Kotler et al., 1984) However, designers themselves may also contribute to a lack of understanding and resistance in the company. Some designers tend to create a product intended for an ideal world in which case such product turns out to be perfectly designed but it does not achieve a market success. Additionally, creative individuals often communicate improperly and they create obstacles in the business environment, often among design professionals themselves who are supposed to cooperate (e.g. graphic designers with product designers or environment designers).

Companies, just like designers, engaged in furniture manufacturing should modify their present business practice and turn to mutual and more efficient communication and collaboration, by using their multidisciplinary knowledge.

\section{Conclusion}

Companies engaged in the furniture manufacturing sector in the Republic of Croatia find it ever more difficult to cope with the competition of large international organisations and associations which, in marketing and production terms, are incomparably stronger. Thereby, a systematic and continuous product policy management as well as adequately defining furniture market properties are significant for company's competitiveness and the question is how much and in what way the companies engaged in the furniture manufacturing sector actually use them. For this reason, the research objectives in this paper are to carry out the analysis of the present condition as well as of previously conducted research projects on the role of design in defining market properties and product policy in the furniture industry, and to investigate to what extent design profession has been involved in the function of product policy and in the teams which define the market properties of products in the furniture industry.

With a purpose to fulfil the objectives of this paper, a primary research on the sample of designers and companies has been carried out. The research results showed that adequately managed product policy and well defined market properties of products, among other things, represent important factors for the market success of the new product. Furniture represents a product for which design, in the full sense of this word, is extremely important. A good product design enables a company to differentiate itself from its competition and to maintain its market advantage. Considering the fact that product design constitutes an integral element of product development, the responsible persons in a company should be familiar and aware of the reasons which cause problems in company's design management. They should develop the methods and approaches to successfully solve and remove such problems and enable the establishment of better communication and systematic collaboration between the company and designers.

In modern economy, the advantage of certain sector or a company is not primarily reflected in the proximity or wealth of natural resources, in this case wood, but in the level of development of technology, knowledge and innovation of business processes and products. Hence, in the furniture industry, an adequately managed product policy and adequately defined market properties of a future product are of utmost importance. On the other hand, design itself is not enough: it achieves its purpose and its real value in collaboration with its partners, which means companies and end users, thus confirming the research results of author named De Mozota (Borja de Mozota, 2003).

As it has been previously shown in this research, the furniture manufacturers in the Republic of Croatia do not involve designers either in product policy activities, or in defining market properties. While defining a new product, in case they collaborate with a designer, the 
companies do not provide or provide very little information to designer regarding the expected price of the new product, the markets in which such product shall be sold, distribution method, information regarding the expected sale or any similar information resulting from previous research projects and familiar practice. It is therefore possible to conclude that company's business concept is not market oriented which presents a big disadvantage and an obstacle for achieving better competitiveness of the sector as a whole. Designers are not involved in the business policy and in defining market properties of the product, neither are they involved in the entire business process. Consequently, the companies engaged in furniture manufacturing mostly lack their own products and innovative manufacturing programmes which may be protected by intellectual property rights. All of this causes a serious problem and vulnerability to domestic companies from the sector of furniture manufacturing on international market.

The research on the involvement of designers in defining the policy and market properties of products proved that designers are insufficiently involved in such processes. Additionally, the research pointed out to significant differences between business practice and designers' expectations, which confirmed the research results (Sanchez, 2006).

The companies engaged in furniture manufacturing should consider the possibility of involving design managers in coordination and management of product development, as well as communication coordination on the level manufacturer - designer, as has been pointed out by Brown as well (Brown, 2008). At the same time, it is clear that companies should require actual market orientation towards marketing concept in accordance with contemporary business practices.

In this paper, the research and analysis have been carried out on several companies engaged in furniture manufacturing. It would be advisable to repeat the research in other manufacturing sectors, by applying the same method in order to compare whether particular manufacturing sectors have a different business concept as a whole.

In future research projects, it would be definitely useful to analyse expectations and the practice of designers' involvement in defining market properties and product policy, from the point of view of employment, and compare whether the attitudes of designers employed in companies, the so called "in-house" designers, differ from the attitudes of designers with whom the companies collaborate, but who are not in-house employees.

\section{References}

1. Borja de Mozota, B. (2003), Design management: using design to build brand value and corporate innovation, Allworth press.

2. Brooke Dobni, C. (2010), „Achieving synergy between strategy and innovation: The key to value creation", International Journal of Business Science and Applied Management, Vol. 5, No. 1, 2010, pp. 48 - 58;

3. Brown, T.(2008), ,Design Thinking“, Harvard business review, Vol. 86, No. 6, pp. 84-92.

4. Chittuiri, R.(2009): „Emotions by Design: A Consumer Perspective“, International Journal of Design, Vol. 3, No. 2, 2009, available at: http://www.ijdesign.org/ojs/index.php/IJDesign/article/view/577/256 (02.04.2011)

5. Gorm, G., Tore, K., Lynne Zaichkowsky, J. (2010), „Whose design is it anyway ?, Priming designer and shifting preferences", International Joural of Market Research, The Market Research Society, Vol.52, No. 1, pp. $89-110$.

6. Guo, L. (2010), "Product Design and Financial Performance", Design Management Journal, Vol. 5, No. 1, pp. $5-19$.

7. Hrvatski dizajn centar, (2005), "Implementacija dizajna u drvnu industriju“, Ministarstvo poljoprivrede, šumarstva i vodnoga gospodarstva, Zagreb/Croatian Design Centre, (2005): "Implementation of design culture and strategy into the Croatian wood sector" , Ministry of Agriculture, Forestry and Water Management.

8. Jolly, A. (2011), The handbook of European Brand Rights Management, Kogan Page Limited.

9. Keller, G.(1975), Design, Vjesnik.

10.Kotler, P.(2004), Marketinška znanja A-Z, Binoza press, Zagreb. 
11.Kotler, P., Rath, A. (1984), "Design, a powerful but neglected strategic tool", Journal of Bussiness Strategy, Vol. 5, No. 12, pp. 16

12.Nathan associates Inc., J.E. Austin Associates Inc. (2003): „Strategija konkurentnosti za hrvatski drvni klaster", USAID Hrvatska inicijativa za konkurentnost, Zagreb/ Nathan associates Inc., J.E. Austin Associates Inc. (2003): "Competitiveness strategy for Croatian wood cluster", USAID Croatian Competitiveness Initiative, Zagreb

13. Ministarstvo regionalnog razvoja, šumarstva i vodnoga gospodarstva, (2011): „Operativni program razvoja prerade drva i proizvodnje namještaja 2011-2014". / Ministry of Regional Development, Forestry and Water Management, (2011): "Operative Programme for Development of Wood Processing and Furniture Manufacturing 2011-2014"

14.Previšić, J., Ozretić Došen, Đ. (1999), Međunarodni marketing, Masmedia.

15.Sanchez, R. (2006), "Integrating Design into Strategic Managment Process", Design Managment Review, Vol.17 No. 4, pp. $10-17$.

\section{About the author}

Romina Radovic, MSC, is a CEO at Romicom Ltd., President of the Institute for the Development and Management of design and intellectual property-IDEA +, and permanent court expert in the field of construction and sub-branch of activities Interior and Design, and for the branch of activities the economy, sub-branch of activities are intellectual and industrial property, brand name and marketing. Her primary research interests lie in the management and product development, and business and design's innovation, product design, product management; manage product brand, design's value and brand value of products. While working in the profession for many years, she participated in numerous activities related to the development, design and competitiveness of Croatian products, participant's media workshops and roundtables, as well as professional seminars and lectures in the field of architecture, design and marketing. The author can be contacted at romina.radovic@romicom.hr 